\title{
Potential Tax Implications of NCAA Family Travel Allowances
}

\author{
Valrie Chambers and Michael E. Bitter \\ Stetson University
}

\begin{abstract}
Universities are under fire for their allocation of the significant revenues generated from their highest-profile sports: football and men's basketball. The criticism stems from the allocation of funding, where most revenue is used to pay salaries to coaches and athletics administrators instead of benefiting the participating studentathletes. The family travel allowance is one small appeasement in addressing such criticisms. While this travel benefit is a generous gesture, there are potential income tax consequences. This article reviews the potential taxation of the travel allowance program. The article concludes with a sample university policy for the provision of travel stipends and a recommendation for an Internal Revenue Service ruling regarding the taxability of this benefit.
\end{abstract}

Keywords: income tax, stealth tax, extra benefits, cash stipends, student-athlete compensation

The National Collegiate Athletics Association (NCAA) and its Division I member institutions are susceptible to criticism because of the exorbitant sums of money generated by the collegiate sports of football and men's basketball and the relatively small portion of funds that have directly benefited the student-athletes in those sports. For example, in 2014-2015 (i.e., the first year of the College Football Playoff [CFP]), football distributions to Division I Football Bowl Subdivision (FBS) conferences and members were close to \$506 million ("College Bowl Payouts," 2015). After expenses, the excess available to conferences and institutions to pay athletic administrators' and coaches' salaries and fund operations for all sponsored sports was almost \$406 million. In addition, the NCAA distributed over \$547 million, including over \$193 million from the basketball fund, during the 2014-2015 fiscal year (Deloitte \& Touche, 2015). The majority of the NCAA revenue distribution is generated by the Division I men's basketball tournament contract with CBS and the Turner Broadcasting System, which generated $\$ 720$ million in fiscal year 2015(Deloitte \& Touche, 2015). The total value of the contract, which runs from 2011 to 2024, is $\$ 10.8$ billion (Deloitte \& Touche, 2015).

Chambers and Bitter are with the M.E. Rinker, Sr. Institute for Tax and Accountancy, Stetson University, Celebration, FL. Please address author correspondence to Valrie Chambers at valrie.chambers@ stetson.edu 
Critics charge that some of the revenue should directly benefit the studentathletes who significantly contribute to the revenue generation by participating in those sports (DeGrazia, 2014; Gregory, 2013; Nocera, 2011; NPR, 2014). However, pay-for-play would undercut the principle of student-athlete amateurism, and the NCAA opposes such undercutting. However, perhaps as gestures of goodwill, the NCAA recently allowed Division I student-athletes to receive athletics aid equivalent to the full cost of university attendance as well as a travel allowance for family members of student-athletes to attend select postseason contests (NCAA, 2015b).

On January 6, 2015, the NCAA announced the launch of a travel allowance program that provides certain family members of student-athletes participating in the CFP Championship Game or the NCAA Division I men's or women's basketball Final Four up to $\$ 4,000$ (NCAA, 2015b). The allowance should be used to assist families with travel expenses (i.e., lodging, transportation, meals) while attending the event (NCAA, 2015b). Although this travel benefit may be reasonable in many respects, there has been little discussion of the tax consequences for the studentathlete or his/her family receiving this benefit from either his/her university or an independent third party (i.e., the NCAA or CFP). This article reviews the new travel allowance policy, the taxation of these benefits and scholarships in general, issues arising when student-athletes are not classified as employees, and how the taxation of this benefit might interplay with a few other frequently occurring tax provisions for families with college students. Further, this analysis includes responses from an NCAA official following inquiries from the authors.

\section{NCAA Rules}

To participate in NCAA Division I athletics, a student-athlete must meet minimum initial and continuing academic eligibility standards as outlined in Bylaws 14.3-14.4 (NCAA, 2015a). However, athletic scholarships are primarily awarded based on athletic ability, often irrespective of financial need or academic merit; some student-athletes may already be subject to taxes on earned or unearned income (Colombo, 2010). Historically, any institutional financial aid based on athletics ability exceeding the full grant-in-aid ${ }^{1}$ was impermissible under NCAA Bylaw 15.1 (2014a), rendering the student-athlete ineligible. In essence, such amounts were considered pay for participation in intercollegiate athletics (Colombo, 2010). Recently, the NCAA modified its rules with Bylaw 15.02.5, which increased the amount of a full grant-in-aid up to the cost of attendance (NCAA 2015a).

Many of the student-athletes participating in Division I FBS receive a full athletic grant-in-aid. ${ }^{2}$ According to NCAA Bylaw 16.8.1 (2015a), these studentathletes are also permitted to receive reimbursement for certain expenses from their institution, their conference, or the NCAA to represent their institution in practice, competition, or activities incidental to practice and competition.

For example, the NCAA permits certain benefits to student-athletes and their families in conjunction with conference championships and NCAA tournaments. For example, student-athletes are permitted to accept gifts for participation in conference tournaments (maximum value of \$375 per award), NCAA tournaments (maximum value of $\$ 375$ per institutional award), and football bowl games (maximum value of $\$ 400$ per institutional award) per NCAA Bylaw 16.1.4.1 (2015a). Each 
participant on a conference (national) championship-winning team may receive an award valued at up to $\$ 325$ (\$415) per NCAA Bylaw 16.1.4.2 (2015a). According to the NCAA 2014-2015 Postseason Bowl Handbook (2014b), a maximum of $\$ 550$ in bowl awards can be given to each participant. Student-athletes participating in postseason competition receive six complimentary admissions that can be used for family members or friends per NCAA Bylaw 16.2.1.1.1 (2015a). And NCAA Bylaw 16.6.1.1 (2015a) notes the following:

The institution may provide the cost of actual and necessary expenses (e.g., transportation, lodging, meals and expenses associated with team entertainment functions) for the spouse and children [emphasis added] of an eligible studentathlete to accompany the student-athlete to a postseason football bowl game or an NCAA football championship in which the student is a participant, and in other sports, to one round (conducted at the site) of any NCAA championship in which the student-athlete is a participant. (p. 182)

However, student-athletes and their family members are prohibited from receiving "extra benefits" not permitted by NCAA Bylaw 16.01.1 (2015a) from institutions, institutional employees, or representatives of an institution's athletics interests (i.e., boosters).

\section{The NCAA Pilot Program}

Recently, the NCAA decided to extend benefits to certain family members of select student-athletes in a rather significant way. On January 6, 2015, the NCAA created a pilot program to permit a travel allowance of up to $\$ 3,000$ for certain family members of student-athletes eligible to participate in the CFP Championship game and \$4,000 for participation in the NCAA Division I men's or women's basketball Final Four. Only parents and/or guardians were eligible for the football allowance. However, the NCAA broadened the eligibility for all family members for those competing in the men's and women's Final Four. This allowance is intended to cover travel expenses incurred while attending the event. The amount of the allowance was based on a maximum of $\$ 300$ per night for hotel, $\$ 200$ per day for meals and incidentals, and \$1,500 for transportation (NCAA, 2015a).

For football, the CFP provided funds to the participating institutions in 2015 (The Ohio State University and the University of Oregon), which then disbursed funds to the qualifying family members of student-athletes eligible to participate (NCAA, 2015b). According to an NCAA director of academic and membership affairs familiar with the pilot program, the NCAA left the distribution of the funds to the discretion of the CFP and the institutions (Author 2, personal correspondence, March 3 and April 7, 2015). For the Final Fours, the NCAA itself distributed the travel funds to the participating institutions, which then disbursed funds to qualifying family members of a maximum of 15 eligible student-athletes. Per the same NCAA staff member, the NCAA left the distribution of the funds to the institution's discretion (Author 2, personal correspondence, March 3 and April 7, 2015).

While institutions are not required to submit receipts to the NCAA, they are expected to ensure the funds are used for the intended purpose (Author 2, personal correspondence, March 3 and April 7, 2015). The family members of each 
student-athlete eligible to participate in a Final Fours received travel allowances of up to $\$ 3,000$, while those eligible championship games received an additional $\$ 1,000$ allowance. Although the pilot program may create goodwill for the NCAA and enhance the student-athlete experience, this program may inadvertently create taxation issues for student-athletes and their families. Generally, universities have few federal taxation issues because they operate as not-for-profit organizations. However, there exists some potential employment tax issues related to studentathletes. The next section of this article discusses taxation and college athletics generally, then narrows increasingly to the taxation of student-athletes.

\section{Taxation and College Athletics}

While student-athletes are not currently treated as either employees or an independent contractors, their amateur status is being actively challenged as are the tax-exempt sports associations with whom they are affiliated. For example, Maul (2011) discussed the close association of the National Football League (NFL) with the NCAA and other agencies of both for-profit and not-for-profit status, suggesting that closer scrutiny of the NFL's tax-exempt status is warranted. In April 2015, the NFL announced that it was renouncing its not-for-profit status (Harwell \& Hobson, 2015; Williams, 2016). Both Smith (2010) and Wight (2012) have questioned whether the NCAA should have tax-exempt status, given the profit that certain sports programs earn.

Few scholars have explored the potential issues both the NCAA and its member schools may face in regard to taxation. Most universities are exempt from federal income taxation due to their classification as nonprofit organizations under Internal Revenue Code (IRC) ${ }^{3}$ Section (§) 501(c). However, IRC $\$ 511$ notes these organizations may still have to pay unrelated business income tax (UBIT) generated from activities unrelated to a $\$ 501(\mathrm{c})$ organization's charitable purpose.

Jensen (1987) observed that when drafting legislation on how exempt entities would be taxed on unrelated business income, neither the U.S. House of Representatives Ways and Means Committee nor the U.S. Senate Finance Committee heard testimony on taxing intercollegiate athletics. Rather, they exempted intercollegiate sporting events on their face, likening them to taxing school plays. The IRS generally supported this position in Revenue Ruling (Rev. Rul.) 80-2964 (1980), exempting the sale of annual broadcasting rights by an exempt entity to intercollegiate events. Several Technical Advice Memoranda (e.g., TAM 7851002, TAM 7851004, TAM 7851005, TAM 7851006) $)^{5}$ issued in 1978 held the same position, defending the value of intercollegiate athletics as "typical" of a well-rounded educational experience as follows:

An audience for a game may contribute importantly to the education of the student-athlete in the development of his/her physical and inner strength and to the education of the student body and the community-at-large in heightening interests in and knowledge about the participating schools. In regard to the student-athlete, the knowledge that an event is being observed heightens its significance, which raises the levels of both competitive effort and enjoyment. (Tech. Adv. Mem.78-51-006, 1978, paragraph 23) 
Jensen (1987) also asserted that the nature of the intercollegiate athletics has become more professionalized and that defending its amateur status is a "pretense." He argued that the rationale for not taxing athletic programs is "grounded in quicksand" (p. 53). Appleby (2010) justified the intercollegiate athletic tax exemption on the basis that it unites and impassions university campuses and provides educational opportunities to student-athletes who otherwise might not be able to attend college. Williams and Seifried (2013a) described how the purpose of the football game system began as a volunteer-based, amateur attempt to generate business for a local economy, consistent in purpose and operations with a tax-exempt entity. Williams and Seifried (2013b) further discussed how the football bowl game system has evolved into an employee-based, for-profit business throughout the sporting year. In both studies, the authors discussed how the lines have blurred between these for-profit operations and the college system tax-exempt status claimed based on the educational and charitable benefits to the participants and community.

Other authors have acknowledged the tax-exempt status of universities but identified their unrelated business practices and activities. In particular, Kaplan (1980) traces the history of UBIT, beginning before 1950, when all income from $\S 501(\mathrm{c})(3)$ organizations was exempt from income tax. Consequently, many universities had tax-free investments in for-profit entities, some of which competed with other taxable for-profit entities. For example, New York University owned the C.F. Mueller Macaroni Company (Kaplan, 1980), which competed against other macaroni companies that paid federal income tax. Critics charged that Mueller's tax-exempt status meant both a loss of revenue for the Department of Treasury and an unfair disadvantage to the macaroni companies that were responsible for paying federal income taxes on profits (Kaplan, 1980). The intent behind reducing any unfair competitive advantage is reinforced in Reg. $\$ 1.513-1(\mathrm{~b})$, through the passage of the UBIT. Vari (1992) examined the effect of TAM 91-47-007, which treated revenue from the college bowl systems as UBIT. Williams and Seifried (2013a, 2013b) examined whether specific business activities and ventures implemented by intercollegiate athletic departments were exempt from taxation or subject to UBIT. Craig and Weisman (1994) identified program and scoreboard advertising revenue as a target for UBIT. They noted that these revenue sources supplement the operating budgets of university athletic programs and are subject to UBIT because they constitute a trade or business that is regularly carried on and not substantially related to the purpose for which the exemption was granted (see also Reg. §1.513-1). ${ }^{6}$ Further, Reg. §1.512(a)-1(d) and (f) severely limits deduction of expenses for overhead and depreciation used to offset advertising revenue because those expenses are incident to the furtherance of the exempt purpose of the organization and are not directly related to the advertising revenue. Corgan (2012) proposed allowing student-athletes to accept endorsement deals, which would presumably result in taxable income. He quoted former National Basketball Association (NBA) great Charles Barkley on former University of Southern California (USC) player Reggie Bush's acceptance of improper college sports benefits from a sports agent as saying,

They're not allowed to do it but we all did it. We wanted some money . . . . I might've wanted a coat during the winter. I might've wanted to help my mom pay some bills. These colleges, they're not giving you any money. They're making tons of money. 
As collegiate sports have evolved to be more businesslike and the tax exemption has begun to shift to include areas of federal income taxation, there is very little applicable literature discussing income taxation from the student-athletes' point of view (Kisska-Schulze \& Epstein, 2014), largely because student-athletes have not generally been exposed to tax implications beyond those of other students. However, as college athletics become more professionalized (Corgan, 2012; DeGrazia, 2014; Gregory, 2013; Jensen, 1987), we must consider whether student-athletes are more exposed to federal income tax. One new benefit provided to student-athletes, but not students in general, may indeed be taxed at a federal income tax level: cash payments to certain family members of student-athletes who participate in select intercollegiate football and basketball championships contests, earmarked for family travel to those games.

\section{Taxation of Student-Athletes}

Currently, student-athletes are generally treated as unpaid amateurs, as opposed to university employees. Until recently, the NCAA limited a "full grant-in-aid" (i.e., a full athletic scholarship) to the cost of tuition and fees, room and board, and course-related books per NCAA Bylaw 15.02.5 (2014a). The U.S. government excludes these scholarships from taxation as reduced by the amount of any other scholarship or grant awarded the student-athlete (excluding a Pell Grant) and by the amount of wages from any student-athlete employment during the school year (Rev. Rul. 77-263, 1977).

Many current and former student-athletes have legally questioned their employment classification while in college, but authorities have refused to rule on the issue. For example, in 2014, Northwestern University football players petitioned Region 13 of the National Labor Relations Board (NLRB) to be declared as statutory employees of the university to be allowed to unionize (NLRB, 2015). On March 26, 2014, Region 13 of the NLRB found that eligible football players receiving athletic grant-in-aid scholarships were employees and allowed to unionize. Northwestern University appealed the decision to the national NLRB. On August 17, 2015, the federal NLRB overturned the regional ruling, noting the NLRB was not empowered to rule as to whether the football players were employees and that "asserting jurisdiction in this case would not serve to promote stability in labor" (NLRB, 2015, p. 1). This later ruling does not preclude employee status for student-athletes, as the NLRB declined to rule on the student-athlete employment classification.

Student-athletes have also sued the NCAA for compensation for the use of their names, images, and likenesses. In O'Bannon v. NCAA (2015), a collective of former student-athletes led by former University of California-Los Angeles (UCLA) men's basketball player Ed O'Bannon sued the NCAA regarding the use of former and current student-athletes' images for commercial purposes. On August 8, 2014, the District Judge Claudia Wilken ruled that the NCAA's rules and bylaws restrain free trade and violate antitrust legislation (O'Bannon v. NCAA, 2015). She further ordered that schools should be allowed to offer full cost-of-attendance scholarships to athletes. These scholarships cover cost-of-living expenses beyond tuition, fees, and other related expenses. In addition, Judge Wilken ruled that colleges could place up to $\$ 5,000$ per athlete into a trust for each year of the student-athlete's eligibility. 
The NCAA appealed, maintaining that paying its student-athletes violated the concept of amateurism in sports (O'Bannon v. NCAA, 2015).

Before the appeal, however, the NCAA Division I membership passed Autonomy Proposal No. 2014-13 in January 2015, which was codified as Bylaw 15.02.5 and amended NCAA Division I bylaws by redefining a "full grant-in-aid" to include not only tuition and fees, room and board, and books, but also "other expenses related to attendance" up to the institution's cost of attendance (NCAA, 2015a). In September 2015, the Ninth Circuit Court of Appeals asserted its jurisdiction to rule in this case and affirmed the lower court decision that the NCAA was subject to antitrust laws (O'Bannon v. NCAA, 2015). The Appeals Court also agreed that schools should be allowed to offer full cost-of-attendance scholarships to student-athletes. However, they were divided regarding the additional $\$ 5,000$ per student-athlete per eligibility year trust fund, ultimately noting that the lack of compensation is precisely what makes student-athletes amateurs. As of this writing, the O'Bannon plaintiffs are appealing this ruling to the U.S. Supreme Court (Perlman, 2016).

There has been little or no literature on student-athletes being independent contractors, but academics and pundits have addressed and argued for studentathletes being paid as employees. McCormick \& McCormick (2006) noted that a student-athlete's daily obligations meet the legal standard of employee under the National Labor Relations Act since his/her daily burdens and obligations exceed the burdens and obligations of most university employees and is primarily commercial in nature. The duties of student-athletes have been compared with those of graduate student assistants, who are treated as university employees, on a point-by-point basis, finding that the duties of student-athletes exceed those of graduate student assistants (Hebel, 2014). Caughron and Fargher (2004) discuss employment tax subjects, including the difference between employee and independent contractor in sports and recreation generally. If found to be employees, student-athletes would be subject to the employment taxes. Kisska-Schulze and Epstein (2014) provide an in-depth discussion of state tax implications if student-athletes were to be paid as employees, including the states' constitutional rights to tax-paying student-athletes. They further discuss that being located in a no-income-tax state may provide a competitive advantage for universities in recruiting as well as being subject to sunshine laws that require the wages of all public employees to be disclosed if working for a public institution. If student-athletes were classified employees, both their wages and fringe benefits would be subject to income taxation except where exempted. The reclassification could happen from a court decision or Congressional action, or, as Kisska-Schulze \& Epstein (2016) note, from an independent revisitation of the interpretation of the law from the IRS.

However, there is still a question of whether current and former student-athletes are employees and whether universities provide financial support to studentathletes in the form of scholarships. Consequently, there is a dearth of literature on the federal income tax effects of student-athletes being paid beyond the cost of attendance generally, and the authors could find no tax literature on the family travel allowance specifically, even though it could portend more liberal payments and benefits to student-athletes who participate in high-revenue sports. The next section of this article addresses the federal tax implications of the family travel allowance, beginning with the taxation of student-athletes' income generally, and 
fringe benefits and scholarships more specifically. This is followed by important but indirect tax issues that may be triggered if the pilot program benefits prove to be taxable, including the effects of earned income credit, dependency exemptions, "kiddie tax" rules, alternative minimum tax, taxation of foreign income, and assignment of income. Then, gift tax treatment, which is the alternative to treating the travel allowances as income, is discussed.

\section{Taxation of Student-Athletes' Income}

IRC §6012 explains that taxpayers who can be claimed as dependents by someone else are required to file their own income tax return if their unearned income is more than a certain amount (e.g., $\$ 1,050$ for 2016), or their earned income is more than the standard deduction amount for the year (e.g., \$6,300 for 2016, Rev. Proc. 2015-53, n.d.). ${ }^{7}$ IRC §61(a)(1) provides that an individual's gross income includes all income from whatever source derived, including "compensation for services, including fees, commissions, fringe benefits, and similar items," unless specifically excluded. One such exclusion is found in IRC $\$ 117$, which explicitly excludes amounts received as a scholarship by degree candidates at an educational institution. The pilot program income, if not excludible, may be significantly large enough to trigger a federal income tax filing responsibility, especially if that income is deemed to be unearned.

Scholarships are generally received as cash or a reduction in qualified educational expenses, but this need not be the case. Reg. \$1.61-1(a) elaborates that gross income includes "income realized in any form, whether in money, property, or services. Income may be realized, therefore, in the form of services, meals, accommodations, stock, or other property, as well as in cash.” Reg. §1.61-14 lists other examples of miscellaneous items of gross income, including treasure trove, which is found money for which the rightful owner is presumed undiscoverable. As such, it is possible that the payments made under the pilot program would be classified as scholarship income.

\section{Fringe Benefits}

Student-athletes often receive free transportation, meals, and lodging while traveling to games, which is included in tax-free scholarship receipts. If student-athletes were considered employees who received the same allowance in a flat amount without having to provide travel receipts, this allowance would be considered a taxable fringe benefit under an unaccountable reimbursement plan (Reg. \$1.62-2), subject to substantiation requirements for employees found in Reg. \$1.274-5. While meals and lodging of an employee for the convenience of the employer is exempt from taxation (IRC §119), benefits for family members of employees are specifically not exempted from taxation (IRC $\$ 274(\mathrm{~m})(3)$ ). Pilot program payments made to family members may be taxable income, much like a fringe benefit would be.

\section{Scholarships Excludable From Income}

IRC $\S 117(b)(1)$ defines a qualified scholarship as "any amount received by an individual as a scholarship or fellowship grant to the extent the individual establishes 
that, in accordance with the conditions of the grant, such amount was used for qualified tuition and related expenses." Tuition, fees, books, supplies, and equipment required for enrollment are qualified expenses. Treasury Regulation \$1.117-3(a) (1985) clarifies that a scholarship is

An amount paid or allowed to, or for the benefit of, a student, whether an undergraduate or a graduate, to aid such individual in pursuing the individual's studies. The term includes the value of contributed services and accommodations and the amount of tuition, matriculation and other fees that are furnished or remitted to a student to aid the student in pursuing the student's studies.

Where a student is a candidate for a degree at an educational institution, the IRC $\$ 117$ exclusion shall not apply to payments for teaching, research, or other services in the nature of part-time employment that are required as a condition of receiving the scholarship, except where that teaching, research, or other services are required of all candidates as a condition for receiving a particular degree (IRC $\S 117($ b)(1)). Further, for the scholarship to be excludable, the university cannot require the students to participate in a particular sport, require any particular activity in lieu of participation, or cancel the scholarship if the student cannot participate (IRC $\$ 117(\mathrm{a})$ ). That is, scholarships are excludable even if services are performed, provided those services are primarily the education and training of the individual recipient and not compensation for past, present, or future employment services or for the benefit of or under the supervision of the grantor (Reg. §1.117-4(c)).

In Bingler v. Johnson (1969), Johnson worked for Westinghouse Electric Corporation, which gave him a scholarship for tuition. He was also given an educational leave of absence to pursue his doctoral degree full-time, with an additional stipend ranging from $70-90 \%$ of his prior salary plus a family allowance. During that time, he retained seniority status and received insurance, stock option privileges, and other employee benefits. Johnson had to report on his progress and agree to work for Westinghouse for at least two years after completing his degree. The IRS asserted that the stipend was taxable as gross income; Johnson argued that the amounts received from Westinghouse while he was on leave were excludable scholarship income under IRC \$117. The District Court found for the IRS; Johnson appealed. The Appellate Court reversed, and the IRS appealed. The U.S. Supreme Court, supported Reg. §1.117-4(c), and found that the money that Johnson received was taxable compensation. Where a scholarship is conditioned on either past, present, or future services by the recipient, the scholarship is considered wages for purposes of IRC $\$ 3401\left(\right.$ a) and subject to FICA withholding. ${ }^{8}$

An undesignated, qualified scholarship can be excluded up to the aggregate amount of qualified educational expenses, regardless whether those specific scholarship funds were used to pay the educational expenses. However, a scholarship that is specifically earmarked for another, nonexcludable purpose must be included in income (Conf. Rep't. No. 99-841, pp. 11-16; Prop Reg. §1.117-6(c)(1)). Related to intercollegiate athletics, any amounts exceeding the allowable educational expenses are generally not considered a scholarship but rather pay for participation. Colombo (2010) noted that pay-for-play is impermissible under NCAA rules and would generally render the student-athlete ineligible. That is still true; however, what constitutes permissible financial aid under NCAA rules, as noted earlier, has 
changed substantially. For instance, the travel allowance was approved by the NCAA Division I Subcommittee for Legislative Relief through its waiver process. As such, this benefit is permissible and does not result in loss of eligibility under NCAA rules because the benefit is neither considered financial aid nor an "extra benefit."

\section{Tax Categorization of Includable Scholarship Income}

When scholarship funding is includable in the calculation of taxable income, it is treated as "other income" when no services are performed. In other words, it is not subject to federal income tax withholding under IRC $\$ 3402$, the Federal Insurance Contribution Act (FICA) withholding under IRC $\$ 3102$, or the Federal Unemployment Tax Act (FUTA) under IRC \$3301. Instead, as explained in IRS Publication 970 (2016b), it is entered as wages on Line 7 of the Form 1040, regardless whether a W-2 was received. Further, scholarships are not considered earned income for purposes of the earned income credit (EIC; IRC §32), except where those scholarships are amounts paid for teaching, research, or other services.

\section{Earned Income Credit}

The EIC is "a refundable credit designed to help offset the effect of employment taxes on compensation paid to low-income taxpayers and to encourage lower income taxpayers to seek employment" (Spilker et al., 2015, p. B-5). Because it is refundable, taxpayers with this credit may receive a refund of federal income taxes even if they have had no income tax withheld or remitted no estimated payments. To claim the EIC, a taxpayer must have a valid Social Security number, be a U.S. citizen or resident alien, have no foreign income, and not be classified as married filing separately (IRC \$32). The amount of the credit depends in part on the number of qualifying children that the taxpayer may claim for dependency exemption purposes. Low-income parents or others claiming the student-athlete as a qualifying child may be eligible for the EIC provided that they have both earned income-including wages, tips, and self-employment income-and no or insignificant investment income (including interest, dividends, net capital gains, net passive income, and nonbusiness rents and royalties) (IRC §32). Significant investment income varies by year; for 2016, the amount of investment income is considered significant if it exceeds \$3,400 (Rev. Proc. 2015-44).

A student-athlete with a qualifying child might qualify for the EIC of his own accord. However, a student-athlete without a qualifying child would have to maintain a principal residence in the United States for more than half of the tax year, not be claimed as a dependent on another's return, and the student-athlete's spouse must be at least 25 years of age and under age 65 by the close of the tax year. Thus, the age restriction would generally disqualify student-athletes who are not claimed as a qualifying child on another taxpayer's return (IRC §32). The amount of the EIC is scaled by the number of children for up to three qualifying children; the maximum EIC is $45 \%$ of earned income eligible for the credit $(\$ 13,930$ for 2016 , Rev. Proc. 2015-44). Pilot program income, if deemed earned, would affect the amount of earned income credit directly. Otherwise, it could affect the amount of earned income credit indirectly. 


\section{Dependency Exemptions and Scholarships}

A taxpayer may take a fixed deduction for each individual who qualifies as a dependent of the taxpayer (IRC $\$ 151(\mathrm{c})$ ). To qualify as a dependent, an individual must (a) be a citizen of the U.S. or a resident of the U.S., Canada, or Mexico; (b) not file a joint return with the individual's spouse, except where the joint return shows no tax liability and would not show a tax liability if they were to file separately (Rev. Rul. 54-567); and (c) be either a qualifying child or a qualifying relative of the taxpayer (IRC §152). To be a qualifying child, the dependent must be a child or descendant of a child or a sibling or descendant of a sibling, and, if a full-time student, under age 24 at the end of the year and living in the same principal residence as the taxpayer for more than half of the year, not counting time spent away for education (IRC $\$ 152(\mathrm{c})(3)(\mathrm{A})$ ). In addition, the qualifying child must not have provided more than half of his or her support for the year (IRC \$152). While private or public education costs are part of a dependent's support (see e.g., Rivers $v$. Commissioner, 1960), athletic scholarships are not considered support for dependency exemptions where the recipient is a son or daughter of the taxpayer (Reg. $\S 1.152-1(\mathrm{c})$; James B. Heidel, 56 TC 95 1971). However, includable scholarships are taxable to the recipient and may trigger "kiddie tax," regardless of parental support. As such, pilot program payments, if includable as taxable scholarships, would be paid at the higher "kiddie tax" rates.

\section{“Kiddie Tax" Rules}

"Kiddie tax" applies to the unearned income of children under the age of 19 , or under the age of 24 if the child is a full-time student with at least one living parent at the close of the tax year unless that child files a joint return for the tax year (IRC $\S 1(\mathrm{~g}))$. This law was passed as part of the Tax Reform Act of 1986 to address the concern of Congress that high-wealth taxpayers were shifting their income tax liabilities to their minor children to take advantage of those children's extra standard deductions and lower tax brackets (House Report No. 99-426, 1985; Senate Report No. 99-313, 1986). Originally, only the unearned income (net of the allowable deductions for children under the age of 14) was subject to the parents' highest marginal tax rate (Tax Reform Act of 1986). Small changes that included modifying the amount of income exempt from taxation and shifting the advantage from children filing separately from their parents were made to the "kiddie tax" over time (Rubenstein, Madison, \& Royalty, 2015). However, in the Tax Increase Prevention and Reconciliation Act of 2005, Congress changed the applicable age for children to include all children under the age of 18, unless the child files a joint return. With virtually no comment, Congress amended the age again in 2007 to include children under the age of 24 who were full-time students and whose earned income did not exceed one-half of their support (Small Business and Work Opportunity Tax Act, 2007).

For "kiddie tax" to apply, the child must not have received earned income in excess of one-half of his or her support, which does not include taxable scholarship income. Earned income for purposes of kiddie tax is defined in IRC $\S 1(\mathrm{~g})$ and $\$ 911(d)(2)(I R S, 1986)$. "Kiddie tax" provisions essentially tax the unearned income of a dependent child at the parents' higher marginal federal income tax rate, 
to the extent that the unearned income exceeds twice the basic standard deduction allowed to dependents $(2 \times \$ 1,050=\$ 2,100$ for 2016, Rev. Proc. 2015-53). Earned income is taxed at the child's tax rate (IRC $\$ 1(\mathrm{~g}))$. Where the unearned income results from an investment made from the earnings of a child, the income is still subject to "kiddie tax" (IRS, 1986). ${ }^{9}$

"Kiddie tax" is generally filed on Form 8615 with the child's Form 1040 for the year but may be combined with parents' income on the parents' tax return. The expansion of kiddie tax in 2007 to children up to age 24 resulted in some unintended consequences (Chanel, 2015; Muehlmann, Baez, \& Burnaby, 2012; Rubenstein et al., 2015) and may affect the taxation of NCAA allowances for family travel. Further, the IRS changed the title of its Form 8615 from "Tax for Certain Children Who Have Investment Income of More Than \$1,900" in 2012 to "Tax for Certain Children Who Have Unearned Income," beginning in 2013. The new title reflects the IRS's position that "kiddie tax" includes scholarship income. Unearned income is not well defined in the Internal Revenue Code; however, the Instructions for Form 8615 (2014) now state the following:

Unearned income includes taxable interest, ordinary dividends, capital gains (including capital gain distributions), rents, royalties, etc. It also includes taxable social security benefits, pension and annuity income, taxable scholarship and fellowship grants not reported on Form W-2 [emphasis added], unemployment compensation, alimony, and income (other than earned income) received as the beneficiary of a trust. (p. 1)

Perhaps due to the expansion of the children's age, the newness of the instructions of the form, and the fact that the change to NCAA allowances are recent, there is little guidance on how the new allowances are to be treated for tax purposes.

\section{Alternative Minimum Tax}

Alternative minimum tax (AMT; IRC §55) may also apply to families with children. Individual AMT was originally conceived to prevent wealthy taxpayers from avoiding income tax by using deductions, exemptions, losses, and credits to reduce or eliminate income tax liabilities (IRS, 2007). Because AMT is designed to apply to higher-income taxpayers and children's taxable scholarship and other unearned income is treated as the parents' income, this scholarship income could affect the parents' AMT. Currently, about 4.5 million taxpayers are assessed AMT and this number is expected to rise to 6 million by 2022 ("Model Estimates," 2015).

AMT is complicated and is roughly calculated by taking regular taxable income, adding back tax preference items, and adding or subtracting tax adjustments to arrive at Alternative Minimum Taxable Income (AMTI; IRS, 2007). The AMT exemption is subtracted from this number (IRS, 2007). An essentially flat tax rate of either $26 \%$ for lower income levels of AMT or $28 \%$ for higher levels of AMT is multiplied by AMTI to arrive at the tentative tax, from which applicable credits other than credit for prior year AMT are subtracted (IRS, 2007). If this tax is larger than the regular income tax assessed, credits for prior year AMT are 
subtracted to bring the tax down to, but not below, the amount of regular income tax (IRS, 2007). Pilot program payments, as included in regular taxable income, could be subject to AMT.

\section{Taxation of Foreign Income}

U.S. citizens pay tax on their worldwide income (IRC $\S 862(a)$ ), but where international-sourced income is also taxed by another country, the taxpayer may claim a foreign tax credit to reduce the effects of double taxation (IRC §904). Without this credit, taxpayers could theoretically pay both the U.S. income tax and the income tax in a foreign country that together, in high tax rate jurisdictions, exceed $100 \%$ of the earnings in the foreign country. The amount of the foreign tax credit applied against a U.S. federal income tax return is the lesser of the U.S. tax on the foreign income or the foreign tax paid on the foreign income. In certain cases, a foreign earned income exclusion or a foreign tax deduction may be taken instead of the foreign tax credit. The foreign tax deduction is valuable only to taxpayers who itemize their deductions. The foreign earned income exclusion is available only to taxpayers who live in the foreign country for 330 days in a consecutive 12-month period (IRC §911). Currently, the travel stipend has applied to postseason events held in the United States, so the discussion of foreign taxation is tangential. However, as travel stipends expand, discussion of the treatment of foreign income could become increasingly important.

\section{Assignment of Income Doctrine}

Cash payments intended to reimburse family members for travel expenses incurred might be additional gross income to the student under the assignment of income doctrine subject to the IRC $\S 117$ scholarship exception because the payment to family members is traceable to the student-athlete's participation in that athletic event. For example, in Lucas v. Earl (1930), the Supreme Court ruled that income tax is assessed to the person who earns the income, regardless of who has the right to receive the income, noting that the Court must disregard income shifting attributions "by which the fruits are attributed to a different tree from that on which they grew" (page 281 U.S. 115). This passage is so embedded in income tax law that the assignment of income doctrine is also known as "the fruit of the tree" doctrine. ${ }^{10}$ That is, even though a family member may receive the pilot program payment, it is possible that the amount of the payment would be income attributable for tax purposes to the student-athlete.

\section{Tax Categorization of Gifts}

If the travel allowance is not treated as compensation or scholarship income, it may be a gift from the source to the student-athlete's family. Gift taxes are levied on donors who make transfers of property to a donee within the United States in an amount in excess of the annual exclusion amount (IRC \$2501). The annual exclusion amount for 2016 is $\$ 14,000$ (IRC $\$ 2503$; Rev. Proc. 2015-53). In addition 
to the annual exclusion, there is an unlimited gift tax exclusion for amounts paid on behalf of a donee directly to an educational organization for tuition payments, regardless of the type of relationship between the donor and donee (IRC \$2503(e)). In addition, up to $\$ 5.45$ million of total taxable gifts can be offset by a Unified Credit for 2016 (Rev. Proc. 2015-53). The maximum lifetime taxable gifts that can be offset by the Unified Credit under IRC $\$ 2010$ has varied widely over the years. In 2001, for example, that credit offset $\$ 675,000$ in taxable gifts (Taxpayer Relief Act, 1997). The variation is important for planning because the stated maximum can change at any time, which could become a critical issue for the donor in the future.

The recipient of the gift is not taxed, but the party making the gift may be (IRC §6019). Gifts to one's own spouse are excluded from gift tax (IRC §2523), which may come into play if a student-athlete is married. Similarly, gifts to one's own minor children are considered support (IRC §152) and, therefore, are not subject to a gift tax. Assignment of benefits is an example of an indirect gift (Reg. $\$ 25.2511-1$ ). Gifts are valued at their fair market value on the date of the gift (IRC $\$ 2512$ ). The donee of a gift may disclaim the gift in writing to the transferor, provided the beneficiary neither accepts any of the benefits of the transferred property nor directs where the disclaimed gift passes (IRC §2518).

\section{Discussion}

The amount of the NCAA family travel allowance may well be in excess of qualified educational expenses since it is not directly related to the student-athlete's education and training costs that qualify for the scholarship exclusion. Therefore, because the family allowance is intended to cover family travel costs, it would not appear to be covered by the scholarship exclusion amount per IRC $\$ 117$, especially in situations where a student-athlete is already receiving a full grant-in-aid. The federal income tax implication is that the travel allowance money would be taxable income to the student-athlete and count toward the student-athlete's portion of providing his or her support for purposes of the dependency exemption. The classification of the income is still unclear. It might ultimately be ruled nonemployee income of some type, although the income is not reduced to the player's possession and appears to be primarily for the benefit of the family, as opposed to the student-athlete. In most states, state income taxes would also be commensurately affected, which is significantly troubling for athletes. For example, Kisska-Schulze \& Epstein (2014) noted that the statutory language in North Carolina could result in a student-athlete being deemed a resident of two states simultaneously, possibly subjecting the student-athlete to double taxation and a heightened potential for state tax audits. For student-athletes who reside, attend school, or play in states with an income tax, the potential tax problems may occur at both the state and federal level, greatly complicating the tax situation of the student-athlete and possibly his or her family.

Further, as competitions evolve, international tax implications are a distinct possibility. For example, a collegiate football game featuring Penn State University and the University of Central Florida was played in Dublin, Ireland, on August 30, 2014 ("Penn State to Open 2014," 2013). NCAA Division I men's basketball teams participate in the "Battle 4 Atlantis" tournament in the Bahamas each year 
in November (Battle4Atlantis, 2016). If stipends were paid in conjunction with a foreign competition, student-athletes could be responsible for taxes in multiple countries (Kisska-Schulze \& Epstein, 2013). While there is a foreign tax credit to offset some or all of the foreign taxes paid, there is a layer of complexity that student-athletes, who are commonly between the ages of 18 and 22, may not grasp.

While universities might argue that these funds are a gift to the families of student-athletes, the IRS might argue that they are "other income." One could argue that the travel allowance is primarily for the family's benefit, as opposed to the student-athlete's, and the benefit is not reduced to the student-athlete's possession. There may be insufficient physical presence for the student-athlete when the parents are attending the playoff events. The travel allowance is not directly attributable to the student athlete's actions as an individual; rather, the funds are attributable to the team's success resulting from a joint effort of the members of a varsity athletic team, which makes the payment attributable to the success of the university's team and not of an individual player. Further, because no one person has control over progression to the playoffs, and the payments are not regular and recurring, the travel allowance can be seen as other income to the families receiving them, making it taxable income under IRC $\$ 61$. If the travel allowance is not taxable, it is because it is a gift.

There is no prohibition against a tax-exempt organization giving gifts of up to the annual ceiling of $\$ 14,000$ per person for 2016 (Rev. Proc. 2015-53). The donative intent and acceptance (i.e., use and possession) of the gift are clear, provided the funds are given directly to the family and not to the student-athlete. However, because the travel allowance may be used by whomever the student-athlete designates (because there is not a rule stating it is only for parents), the gift argument to the recipients may be ultimately rejected because the parents need not attend, but the student-athlete needs to be on the team for the travel allowance to be paid. Thus, athlete participation is critical to the payment of the travel allowance, whereas who receives the travel allowance is somewhat discretionary.

Further, student-athletes are likely unaware of the federal income tax implications of receiving this money because the travel allowance program is a new program targeted toward a very small subset of the Division I student-athlete population, and taxation is generally outside a student-athlete's area of expertise. In addition, universities often provide general guidance to students on the taxability of scholarships but may not have considered the tax ramifications of the travel allowances to student-athletes either. If a student-athlete has no other income, the student-athlete probably has little, if any, tax liability. That income which is taxed may well be taxed at the lowest marginal federal income tax rate of $10 \%$ before "kiddie tax" effects, which could fall on the parent, not the student-athlete. If the student-athlete has other taxable income, or if the student-athlete is graduating to employment in the same year that the travel allowance was disbursed, then the student-athlete may well be a student-athlete-taxpayer. At a minimum, universities could assist student-athletes by advising them on the general taxability of such payments, along with directing the student-athlete to the IRS website for guidelines on whether they have to file a tax return (IRS, 2015). However, optimum federal income tax withholding is, in itself, difficult and nuanced for graduating student-athletes because the standard federal tax withholding tables assume a full-year's employment. As explained in 
IRS Publication 505 (2016a), student-athletes working less than 245 days in a year can request a lower amount of federal tax withholdings to be withheld using the part-year method. Further, where a dependent child may be subject to "kiddie tax," the parents' return is also affected. As additional benefits are offered, tax implications expand; yet, because this is a new issue, guidance is lacking.

The parents' tax return itself might be directly affected if it is determined that parents receiving the pilot program payments are to receive a Form 1099-Misc, Miscellaneous Income for the amount of the payment at the end of the tax year. Generally, no amount is withheld for federal income taxes from miscellaneous payments, which would generally result in the parents' owing more or receiving a lower refund than they otherwise would have.

Guidance, in the form of regulations from Congress or the IRS, is needed to determine whether the family travel allowance is excludable, who is primarily responsible for any tax (i.e., the family or the student-athlete), and whether the taxable portion, if any, is to be taxed as earned or unearned income. This guidance should inform institutions of their responsibility for reporting these benefits to the student-athletes and to the IRS. Alternatively, Congress could reexamine tax laws related to student-athlete benefits (alone or as part of a general reexamination of "kiddie tax") in light of their likely continued expansion.

In the meantime, a Private Letter Ruling (PLR) on this issue might be advisable to help determine the taxability of these funds. The university itself may request a PLR because there is a culture supported by laws that protects the student population more than society protects citizens in general, including the Clery Act (Campus Security Policy and Campus Crime Statistics Act, 1990), which requires universities to report crime statistics and security measures; the Credit Card Accountability Card Accountability Responsibility and Disclosure Act (2009), which limits financial companies from soliciting credit applications from individuals under the age of 21; and the Family Educational Rights and Privacy Act (1974), which protects from unauthorized distribution of information that the student wishes to keep confidential. While no such law exists requiring universities to help or protect students in the area of taxation, it is common for universities to have Volunteer Income Tax Assistance programs on campus serving the students and the general population. Further, the universities may be uncertain of their own reporting requirements and request a PLR on those grounds. Their required treatment would then be suggestive of the students' federal income tax treatment. In most states, state income taxes would also be commensurately affected.

Universities should also have a clear policy on the use of funds for travel allowances. The absence of a clear plan may result in a student-athlete's designating a receipt of a payment with no required receipts, which acts much like an unaccountable expense reimbursement plan for employees. In this situation, the student-athlete can direct the disposition of income, and it can either be kept in the student-athlete's household or be given away at the student-athlete's option, which could make it currently taxable followed by a subsequent gift. Further, the taxable portion to the student-athlete would not be offset by a tax deduction for the exempt university. However, the university may be responsible for federal income tax withholding. If this type of payment is enough to reclassify student-athletes from amateur status to employee status, the university may also be responsible 
for Social Security withholding, federal unemployment taxes, and state and local taxes on the payments made.

The mechanics of any plan implemented in accordance with the outlined recommendations is of the utmost importance in protecting student-athletes from adverse tax effects. A better plan for university travel allowances would include several elements that help the student-athlete avoid taxation on travel allowances, if possible, and help the university avoid complex wage reporting requirements at the state and federal levels. In particular, the university should not give funds directly to the student-athlete for distribution. Rather, the travel allowance should be distributed directly to a representative of those traveling as the process currently operates. The travel allowance should reimburse for actual travel to the event. Such a plan might result in an exempt transaction because it comes directly from the university under its policy benefitting student-athletes who win championships. Similar to a varsity jacket or other memento, it is due to winning and given to all student-athletes equally under a uniform policy, and not directed by a studentathlete/employee. Such a policy might read in part as follows:

The University recognizes that during playoff and tournament events that occur away from campus, student-athletes incur additional pressures related to missed class time, the importance of maintaining their academic eligibility, preparation for postseason contests, and participation in all of the related activities (e.g., press conferences, team activities). It benefits the University, where financially feasible, to assist the student-athletes in focusing their attention on the postseason event at hand. One way to do so is to assist family members who can provide moral support and comfort to their student-athlete with the cost of attending postseason events, as permissible under NCAA rules. The University has a policy of directing travel funding for up to two parents/ guardians and two siblings or other extended family members nominated by the parent or guardians in consultation with the student-athlete to the [eligible playoff event]. Funding may be extended to additional family members as may be required to care for an elderly and/or disabled guest during travel and athletic events. The University will assist designated traveling family members, free of charge, with travel arrangements from their home of record to the location of the competition, lodging reservations, and travel-related information. A meal and incidental allowance consistent with published federal per diems will also be provided for event days plus one travel day on either side of each event attended. Travel for student-athletes themselves is covered under a more comprehensive, separate University policy, and is considered University-related travel, and includes transportation, lodging, and meals as is consistent with that policy.

\section{Conclusion}

The new benefits launched by the NCAA in January 2015 provide a travel allowance of up to $\$ 4,000$ to certain family members of student-athletes participating in the CFP championship game or the NCAA Division I men's or women's basketball 
Final Four. This allowance can be used to cover expenses incurred for families' travel, lodging, and meals while attending the event. While this benefit is reasonable in many respects, the student-athlete or his or her family may incur federal income tax consequences for which there is no existing IRS guidance. The NCAA, universities, and student-athletes and their families should be cognizant of the tax consequences of these and any subsequent benefits provided. In addition, the IRS and/or Congress can assist these student-athletes with an unexpected tax bill by providing guidance on how these benefits should be taxed (if at all) and what responsibility the institutions have for reporting these benefits to the student-athletes. In the meantime, a Private Letter Ruling might clarify the appropriate treatment until these issues can be reviewed by a court. In most states, state income taxes would also be commensurately affected. Universities should carefully rewrite their travel allowance policies for the families of student-athletes.

\section{Notes}

1. Per NCAA Bylaw 15.02.5 (2014a), a full grant-in-aid previously consisted of "tuition and fees, room and board, and required course-related books."

2. Per NCAA Bylaw 20.9.9.4(a), an institution sponsoring Division I Bowl Subdivision football must "provide an average of at least 90 percent of the permissible maximum number of overall football grants-in-aid during a rolling two-year period." Given that the annual grant-in-aid limit for these institutions is 85 (per NCAA Bylaw 15.5.6.1), on average, at least 76 football studentathletes are receiving a full grant-in-aid every year.

3. All Internal Revenue Code (IRC) Sections throughout this document are from IRS, 1986.

4. The IRS gives guidance on how to apply the IRC and regulations to specific circumstances and fact patterns in the form of Revenue Rulings.

5. Technical advice memoranda are IRS guidance on the specific application of tax law for a specific transaction and taxpayer.

6. All Revenue Regulations (Rev. Regs.), including Proposed Regulations (Prop. Regs.), throughout the paper are clarifications of the corresponding section in the Internal Revenue Code of 1986, as amended (IRS, 1986). The number following the abbreviation shows the year of issuance and the sequential number of the revenue procedure issued that year. Internal Revenue Code (IRC) sections are also from IRS (1986).

7. A Rev. Proc. is a Revenue Procedure issued by the IRS. The number following the abbreviation shows the year of issuance and the sequential number of the revenue procedure issued that year.

8. See also PLR 200226005 (2002), which says that predoctoral and postdoctoral research fellowships are not treated as wages for U.S. citizens and resident aliens, and such grants are generally excludable from gross income to the extent of qualified educational expenses when received by a degree candidate.

9. Reg. §1.1(i)-1T, Q\&A 8.

10. See also Burnet v. Leininger (1932); Corliss v. Bowers (1930); Helvering v. Clifford (1940); and Helvering v. Horst (1940), all of which make a similar point.

\section{Acknowledgments}

The authors gratefully acknowledge the generous financial support of Stetson University. 


\section{References}

Appleby, A. (2010). For the love of the game: The justification for tax exemption in intercollegiate athletics. The John Marshall Law Review, 44(1), 179-207.

Battle 4 Atlantis. (2016). Retrieved from http://www.atlantisbahamas.com/b4a

Bingler v. Johnson, 394 U.S. 741 (1969).

Burnet v. Leininger, 285 U.S. 136, (1932).

Campus Security Act of 1990. Pub. L. No. 101-542. Codified as 20 U.S.C. §1092(a)(1) (O) and $\$ 1092$ (f)(5) and 34 C.F.R. $\$ 668.46$ and $\$ 668.41$.

Caughron, R., \& Fargher, J. (2004). Independent contractor and employee status: What every employer in sport and recreation should know. Journal of Legal Aspects of Sport, 14, 47-61. doi:10.1123/jlas.14.1.47

Chanel, G. (2015, February 1). The kiddie tax: Inequitable consequences and the need for reform. The Tax Adviser. Retrieved from http://www.thetaxadviser.com/issues/2015/ feb/chanel-feb15.html

College bowl payouts surpass $\$ 500$ million. (2015, April 14). ESPN.com. Retrieved from http://espn.go.com/college-football/story/_id/12688517/college-bowl-game-payoutssurpass-500-million-first-year-college-football-playoff

Colombo, J. (2010). The NCAA, tax exemption, and college athletics. University of Illinois Law Review, 1, 109-163.

Conf. Rep't. No. 99-841, Vol II (PL 99-841) pp. 11-16.

Corgan, M. (2012). Permitting student-athletes to accept endorsement deals: A solution to the financial corruption of college athletics created by unethical sports agents and the NCAA's revenue-generating scheme. Jeffrey S. Moorad Sports Law Journal, 19(1), 371-423.

Corliss v. Bowers, 281 U.S. 376 (1930).

Craig, C., \& Weisman, K. (1994). Collegiate athletics and the unrelated business income tax. Journal of Sport Management, 8(1), 36-48. doi:10.1123/jsm.8.1.36

Credit Card Accountability Responsibility and Disclosure Act of 2009. Pub. L. No. 111-24. Codified throughout 16 U.S.C.

DeGrazia, E. (2014, April 4). College sports as a private enterprise-Just do it. Star Tribune. Retrieved from http://www.startribune.com/college-sports-as-a-private-enterprise-justdo-it/253971241/

Deloitte \& Touche, LLP. (2015). National Collegiate Athletics Association and subsidiaries: Consolidated Financial Statements as of and for the years ended August 31, 2015, and independent auditors' report. Indianapolis, IN: Author. Retrieved from https://www. ncaa.org/sites/default/files/2014-15NCAA_Financial_Statement.pdf

Family Educational Rights and Privacy Act of 1974. Pub. L. No.90-247. Codified as 20 U.S.C. $\$ 1232 \mathrm{~g}(\mathrm{e}) ; 34$ CFR $\$ 99.7$ and distribution also referred to in 20 U.S.C. $\$ 1092$ (a).

Gregory, S. (2013). It's time to pay college athletes. Time. Retrieved from http://content. time.com/time/subscriber/article/0,33009,2151167-1,00.html

H.R. Rep. No. 99-426, at 802 (1985).

Harwell, D., \& Hobson, W. (2015, April 28). The NFL is dropping its tax-exempt status. Why that ends up helping them out. The Washington Post. Retrieved from http://www. washingtonpost.news/business/wp/2015/04/28/the-nfl-is-dropping-its-tax-exemptstatus-why-that-ends-up-helping-them-out/

Hebel, S. (2014, March 27). Employees or not? Graduate student assistants versus scholarship athletes. Chronicle of Higher Education. Retrieved from http://chronicle.com/ article/Employees-or-Not-/145573/

Heidel v. Commissioner of Internal Revenue, 56 T.C. 95 (1971).

Helvering v. Clifford, 309 U.S. 331 (1940).

Helvering v. Horst, 311 U.S. 112 (1940). 
Internal Revenue Service. (1986, as amended). Internal Revenue Code of 1986 (as amended). 26 U.S.C. §1 et seq. Washington DC: Author.

Internal Revenue Service. (1986, as amended). Revenue Regulation §1.1(i)-1T. Washington, DC: Author.

Internal Revenue Service. (1986, as amended). Revenue Regulation §1.61-1(a). Washington, DC: Author.

Internal Revenue Service. (1986, as amended). Revenue Regulation §1.61-14.Washington, DC: Author.

Internal Revenue Service. (1986, as amended). Revenue Regulation §1.62-2. Washington, DC: Author.

Internal Revenue Service. (1986, as amended). Revenue Regulation §1.117-3(a). Washington, DC: Author.

Internal Revenue Service. (1986, as amended). Revenue Regulation §1.117-4(c). Washington, DC: Author.

Internal Revenue Service. (1986, as amended). Revenue Regulation §1.274-5. Washington, DC: Author.

Internal Revenue Service. (1986, as amended). Revenue Regulation §1.152-1(c). Washington, DC: Author.

Internal Revenue Service. (1986, as amended). Revenue Regulation §1.512(a)-1(d) \& (f). Washington, DC: Author.

Internal Revenue Service. (1986, as amended). Revenue Regulation §1.513-1(b). Washington, DC: Author.

Internal Revenue Service. (1986, as amended). Revenue Regulation §25.2511-1. Washington, DC: Author.

Internal Revenue Service. (1986, as amended). Proposed Regulation §1.117-6(c)(1)). Washington, DC: Author.

Internal Revenue Service. (2002). PLR 200226005. Washington, DC: Author.

Internal Revenue Service. (2007). Understanding the alternative minimum tax (AMT) for individuals. Retrieved from http://www.irs.gov/pub/irs-utl/understanding_the_ amt_2007.pdf

Internal Revenue Service. (2015). Do I have to file a tax return? Retrieved from http://www. irs.gov/uac/Do-I-have-to-File-a-Tax-Return\%3F

Internal Revenue Service. (2015). Internal Revenue Service 2015-44. Washington, DC: Revenue Procedure.

Internal Revenue Service. (2015). Revenue Procedure 2015-53. Washington, DC: Author.

Internal Revenue Service. (2016a). Publication 505: Tax withholding and estimated tax. Retrieved from https://www.irs.gov/pub/irs-pdf/p505.pdf

Internal Revenue Service. (2016b). Publication 970: Tax benefits for education. Retrieved from https://www.irs.gov/pub/irs-pdf/p970.pdf

Jensen, E. (1987). Taxation, the student athlete, and the professionalization of college athletics. Utah Law Review, 35(2), 35-58.

Kaplan, R. (1980). Intercollegiate athletics and the unrelated business income tax. Columbia Law Review, 80(7), 1430-1473. doi:10.2307/1122171

Kisska-Schulze, K., \& Epstein, A. (2016). Northwestern, O'Bannon and the future: Cultivating a new era for taxing qualified scholarships. Akron Law Review, 49(4). 771-807.

Kisska-Schulze, K., \& Epstein, A. (2014). Show me the money: Analyzing the potential state tax implications of paying student-athletes. Virginia Sports \& Entertainment Law Journal, 14, 13-49.

Kisska-Schulze, K., \& Epstein, A. (2013). Taxing Missy: Operation gold and the 2012 proposed Olympic Tax Elimination Act. Texas Review of Entertainment and Sports Law, 14, 95-118.

Lucas v. Earl, 281 U.S. 111 (1930). 
Maul, J. (2011). America's favorite "nonprofits": Taxation of the National Football League and sports organizations. UMKC Law Review, 80, 199-220.

McCormick, R., \& McCormick, A. (2006). Myth of the student-athlete: The college athlete as employee. Washington Law Review (Seattle, Wash.), 81, 71-157.

Model estimates: T13-0208 - Aggregate AMT projections and recent history, 1970-2023. (2013, August 26). Tax Policy Center. Retrieved from http://www.taxpolicycenter.org/ numbers/displayatab.cfm?DocID $=3967$

Muehlmann, B., Baez, W., \& Burnaby, P. (2012). Income from student inventions and the kiddie tax. The ATA Journal of Legal Tax Research, 10(2), 1-13. doi:10.2308/j1tr-50267

National Collegiate Athletics Association. (2014a). 2014-2015 NCAA Division I Manual. Indianapolis, IN: Author.

National Collegiate Athletics Association. (2014b). 2014-2015 Postseason Bowl Handbook. Indianapolis, IN: Author.

National Collegiate Athletics Association. (2015a). 2015-2016 NCAA Division I Manual. Indianapolis, IN: Author.

National Collegiate Athletics Association. (2015b). NCAA to pay for family travel under pilot program. Retrieved from http://www.ncaa.org/about/resources/media-center/news/ ncaa-pay-family-travel-under-pilot-program?division $=\mathrm{d} 1$

National Labor Relations Board. (2015). Case No. 13-RC-121359: Northwestern University and College Athletes Players Association (CAPA). Retrieved from https://www.nlrb.gov

Nocera, J. (2011, December 30). Let's start paying college athletes. The New York Times. Retrieved from http://www.nytimes.com/2012/01/01/magazine/lets-start-payingcollege-athletes.html?_r=0

O'Bannon v. National Collegiate Athletic Association, 14-16601, (9th Cir., 2015).

Penn State to open 2014 football season in Ireland. (2013, July 14). USAToday.com. Retrieved from http://www.usatoday.com/story/sports/ncaaf/2013/07/14/penn-stateireland/2515863/

Perlman, M. (2016, March 15). O'Bannon takes student-athlete pay case to high court. Law 360. Retrieved from http://www.law360.com/appellate/articles/772088?nl_ $\mathrm{pk}=\mathrm{a} 7 \mathrm{~b} 52556-8 \mathrm{c} 2 \mathrm{f}-4072-9 \mathrm{e} 17-698 \mathrm{fbb} 959 \mathrm{e} 95 \& \mathrm{utm} \_$source=newsletter\&utm medium=email\&utm_campaign=appellate

Revenue Ruling 54-567, 1954-2 C.B. 108 (1954).

Revenue Ruling 77-263, 1977-2 C.B. 47 (1977).

Revenue Ruling 80-296, 1980-2 C.B. 195 (1980).

Rivers v. Commissioner, 33 TC 935 (1960).

Rubenstein, R., Madison, T., \& Royalty, K. (2015). The kiddie tax and scholarship income: An analysis of the unforeseen tax consequences resulting from the evolution and execution of IRC $1(\mathrm{~g})$ and a roadmap for reform. The ATA Journal of Legal Tax Research, 13(2), 49-64. doi:10.2308/jltr-51134

Senate Report No. 99-313, (1986), at 862.

Small Business and Work Opportunity Tax Act of 2007, Pub. L. No. 110-28, §8241(a), 121 Stat. 190, 199, Codified as Amended at I.R.C. § 1(g)(2)(A) (2007).

Smith, B. (2010). The tax-exempt status of the NCAA: Has the IRS fumbled the ball? Sports Lawyers Journal, 17(1), 117-134.

Spilker, B., Ayers, B., Barrick, J., Outslay, E., Robinson, J., Weaver, C., \& Worsham, R. (2015). McGraw-Hill's taxation of individuals and business entities (7th ed.). New York: McGraw-Hill.

Staff, N.P.R. (2014). Should the NCAA change its rules to pay-for-play? NPR.org. Retrieved from http://www.npr.org/2014/04/03/298763594/should-the-ncaa-change-its-rules-topay-for-play

Tax Increase Prevention and Reconciliation Act of 2005, Pub. L. No. 109-222, §510(a), 120 Stat. 345, 364, Codified as Amended at I.R.C. $§ 1(g)(2)(A)(2005)$. 
Tax Reform Act of 1986, Pub. L. No. 99-514, §1411, et seq. 100 Stat. 2085, (1986).

Taxpayer Relief Act of 1997, Pub. L. No. 105-34, §501(c), Codified as Amended at I.R.C. $\$ 2010$ (1997).

Tech. Adv. Mem. 78-51-002 (n.d.).

Tech. Adv. Mem. 78-51-004 (August 21, 1978).

Tech. Adv. Mem. 78-51-005 (n.d.).

Tech. Adv. Mem. 78-51-006 (n.d.).

Tech. Adv. Mem. 91-47-007 (n.d.).

Vari, F. (1992). The unrelated business income tax and its effects upon collegiate athletics. Akron Tax Journal, 9(1), 111-127.

Wight, B. (2012). College football's BCS (Bowl Charity System?): An analysis of the characterization of BCS Bowls as public charities that receive tax-exempt status. Sports Law Journal, 19(1), 129-144.

Williams, D. (2016). Taking a knee: An analysis of the NFL's decision to relinquish their $\S$ 501(c)(6) federal tax exemption. Journal of Legal Aspects of Sport, 26(2), 127-143. doi:10.1123/jlas.2015-0008

Williams, D., \& Seifried, C. (2013a). Analyzing the prospects of the unrelated business income tax and $\$ 501(\mathrm{C})(3)$ on Division I athletic activities. The Journal of Sport, 2(1), 22-60.

Williams, D., \& Seifried, C. (2013b). The taxing postseason: The potential impact of unrelated business income taxation on college football bowl organizers. Journal of Legal Aspects of Sport, 23(2), 72-90. doi:10.1123/jlas.23.2.72 